\title{
REFORMAS NOS PROGRAMAS SOCIAIS BRASILEIROS: SOLIDARIEDADE, POBREZA E CONTROLE SOCIAL
}

\author{
BRAZIL'S SOCIAL PROGRAMS: \\ SOLIDARITY, POVERTY, AND SOCIAL CONTROL
}

Denise De Sordi ${ }^{1}$

\begin{abstract}
RESUMO: Neste artigo, analiso o processo histórico e social que forneceu substrato à formulação e desenvolvimento do Programa Bolsa Família (PBF). A análise centra-se no período de 1990 a 2014 e observa as formas pelas quais a categoria política da pobreza foi elevada como elemento de centralidade para as ações de programas sociais brasileiros. Nota-se que houve a apropriação dos significados da ideia de solidariedade social, expressa enquanto um projeto que levaria adiante uma identidade política e social de confronto, traduzindo-a em expressão da negociação e da conciliação política amparadas pelo controle social. Evidencia-se que o PBF representou a reorganização institucional dos programas sociais existentes no período de sua criação, enquanto opção política feita em adequação a outras possibilidades de ordenação das estruturas e práticas sociais.
\end{abstract}

PALAVRAS-CHAVE: Programa Bolsa Família, Direitos Sociais, Solidariedade, Pobreza

ABSTRACT: This article aims to analyze the historical and social process that provides social and cultural bases for the formulation and development of the "Bolsa Família" program (BF). By observing the period between 1990 to 2014, it was possible to understand "poverty" as a political concept that has been taken as central to the development of neoliberal postulates considering Brazil's particularities. The meanings of social solidarity expressed a process of political

* Este artigo sintetiza algumas das principais discussões e resultados da tese de Doutorado "Reformas nos Programas Sociais brasileiros: Solidariedade, Pobreza e Controle social (1990-2014)", defendida pela autora, no âmbito do PPGHI/UFU, sob orientação do Prof. Dr. Sérgio Paulo Morais. Disponível em: $<$ http://dx.doi.org/10.14393/ufu.te.2019.615>. O desenvolvimento da pesquisa contou com o financiamento de bolsa PDSE (processo $\mathrm{n}^{\circ}$ 99999.006814/2015-08) e DS provenientes da CAPES.

${ }^{1}$ Doutora em História Social. Pesquisadora do GPEPS/CNPq/UFU. Investigadora associada ao OCVT/FCSH/UNL e ao Grupo de Investigação de História Global do Trabalho e dos Conflitos Sociais IHC/UNL. E-mail: denisends@me.com. 
conciliation and negotiation that carried out social control in favor of the supervision, to the detriment of active political participation. The BF program restructured other social programs that emerged in the 1990s and 2000s, presenting a political choice that prevented other forms from emerging in a renewed social structure of social practices.

KEYWORDS: Bolsa Família Program, Social Rights, Solidarity, Poverty

O Programa Bolsa Família (PBF) é a expressão mais visível tanto da mudança nas concepções que orientam o acesso aos direitos sociais, quanto da forma assumida pelos programas sociais no período da Nova República. É a partir de sua criação e implementação que um novo significado de desenvolvimento social foi estruturado e legitimado no Brasil.

Por sua abrangência territorial e reais méritos, o programa se tornou o símbolo do combate à pobreza no país. Os resultados são expressivos. Em 2015, data de comemoração dos doze anos de existência do PBF, o Governo brasileiro noticiou que "retirou 36 milhões de brasileiros da pobreza extrema" e que nenhuma das "13,9 milhões de famílias atendidas pelo programa no país", estava abaixo da linha definida como de extrema pobreza "pelas Nações Unidas como a de renda inferior a $\mathrm{R} \$ 77$ por mês por pessoa da família". "Com um gasto anual de apenas $0,5 \%$ do Produto Interno Bruto (PIB)" o PBF beneficiava cerca de "um em cada quatro brasileiros, ou seja, 50 milhões de pessoas". Desde 2003 aproximadamente “3,1 milhões de famílias já deixaram voluntariamente o programa" (BRASIL, 2015).

Aliado a outras medidas compreendidas como um conjunto de políticas públicas, o PBF contribuiu para que, pela primeira vez, no ano de 2014, o Brasil fosse retirado do Mapa da Fome divulgado pela Organização das Nações Unidas para Alimentação e Agricultura (FAO) (EXAME, 2018). ${ }^{2}$

Criado em 2003, pela Medida Provisória (MP) n 132, convertida na Lei 10.836/2004 - regulamentada pelo Decreto 5.209/2004, o PBF tem o objetivo

\footnotetext{
${ }^{2}$ Frente as medidas de reformulação e de esvaziamento dos investimentos em políticas sociais durante o governo de Jair Messias Bolsonaro (sem partido), eleito em 2018, dados apontam que o país retornou ao Mapa da Fome. V. DE SORDI: 2021.
} 
prioritário de "combater a pobreza" e dar condições para que as famílias enfrentem a vulnerabilidade tanto

por meio de um benefício monetário que visa o atendimento de necessidades básicas, quanto pelo estabelecimento de condicionalidades que induzem o acesso aos direitos sociais de segurança alimentar, saúde, educação e assistência social. (BRASIL, 2003)

O formato escolhido para o PBF priorizou a reorganização de programas sociais anteriores, criados ao longo dos mandatos presidenciais de Fernando Henrique Cardoso (PSDB) e no início do mandato de Luiz Inácio Lula da Silva (PT). ${ }^{3}$ A Exposição de Motivos (E.M.) que justifica a MP de sua criação, identificou um "consenso" em torno da "importância de programas de transferência de renda" às famílias pobres e apontou que os programas criados ainda no governo de Cardoso por terem sido gestados de forma independente, não se constituíram em uma "uma política dotada dos necessários atributos de complementariedade e integralidade" (BRASIL, 2003). Portanto, em favor da "racionalidade, organicidade e efetividade do Estado na gestão e execução das ações de transferência de renda", o PBF cumpriria o papel de estimular "uma nova cultura institucional", com um "inédito modelo de gestão" para o "enfrentamento da pobreza" e para a "qualidade do gasto social" (BRASIL, 2003).

Deste modo, o PBF foi apresentado como um programa que estaria organizado em oposição às práticas sócio assistenciais implementadas ao longo dos anos da década de 1990. Tal enquadramento foi possível na medida em que a criação do PBF ocorreu com base no compromisso político do governo petista de elevar o combate à pobreza como pauta prioritária para as políticas de desenvolvimento social. Este foi um movimento que colocou em segundo plano

3 Em 1982, o Tribunal Superior Eleitoral reconheceu a fundação do PT autorizando Lula a disputar as eleições. Ele concorreu ao governo de São Paulo e: "incorpora[ou] o apelido ao sobrenome, passando a assinar Luiz Inácio Lula da Silva para que as cédulas preenchidas com o nome 'Lula' fossem validadas". (VANNUCCHI, 2018: p.202-203). Deste modo, a partir deste ponto nos referimos à Luiz Inácio Lula da Silva simplesmente por "Lula", como é popularmente reconhecido na política e história brasileiras. 
mesmo os programas gestados em conjunto com setores organizados da sociedade e implementados a partir de 2003, a exemplo do Fome Zero.

Sublinha-se que mesmo com os importantes e significativos avanços sociais produzidos pelo PBF, a condição de pobreza - eleita como central na elaboração e desenvolvimento das ações de programas sociais - foi a categoria permanente em meio às mudanças engendradas pelas reformas nestes programas. Para tanto, concepções em torno da solidariedade e do controle social precisaram ser ressignificados.

Evidencia-se que o PBF sintetizou uma gama de concepções, valores sociais e políticos relacionados às formas de tratar a questão social da pobreza e de gerir o acesso aos direitos sociais pelos trabalhadores empobrecidos. De certa forma, esse movimento de síntese viabilizou, ao menos na aparência de uma possível aceitação social, a conciliação entre polos sociais inconciliáveis.

Problematizar a constituição do PBF a partir de uma perspectiva que o localize no conjunto dos programas sociais brasileiros - e não simplesmente como um programa novo ou independente do conjunto das políticas sociais, permite compreender que a anunciada nova cultura institucional do programa, operou formas de aceitação e de reinterpretação da condição de pobreza. Deste modo, a ideia da transferência condicionada de renda foi progressivamente aceita como forma de acesso ao alívio material imediato, frente a baixos salários e desemprego, então indicados como condição transitória.

É certo que o concerto social em torno desta aceitação não se deu no espaço de formulação e desenvolvimento do PBF, mas foi construída a partir de leituras e atos que controlaram formas de mobilização social que reivindicavam melhores condições de vida e trabalho. Nota-se, nesse sentido, que as políticas e programas sociais estão em campo oposto àquele das formas de igualdade social mais ampliadas, pois foram moldadas para responder ao trabalho e ao capital a partir da divisão entre os direitos trabalhistas e sociais (GRANEMANN, 2011).

Torna-se, portanto, necessário observar o repertório social, político e econômico do qual o PBF emergiu. Isto implica evidenciar determinados 
acontecimentos localizados nos anos da década de 1990 em diante, considerando a inter-relação destes com fenômenos díspares (THOMPSON, 1981, p.28), de modo a compreender como certas iniciativas foram organizadas em práticas sociais e políticas que sustentaram as reformas feitas nos programas sociais brasileiros nesse período, e que constituíram as bases para o PBF.

Tem-se em conta que as ações anteriores ao programa não tinham por objetivo formá-lo, o que se observa são as escolhas políticas e econômicas que, em conjunto, reordenaram valores para as políticas de assistência social expressas em programas sociais, dos quais, a maior expressão é o PBF. Portanto, este programa é o veículo de observação para a análise empreendida.

A interrogação que guia esta observação é sobre como foi possível que o PBF, enquanto um programa alinhado aos postulados neoliberais de alívio e gestão - e não de transformação - da pobreza, tenha sido legitimado politicamente e aceito socialmente. $\mathrm{O}$ PBF, eleito enquanto marco na elaboração de uma nova lógica para o desenvolvimento social demarcou um movimento de ressignificação para os programas sociais.

Esse processo de ressignificação social abriu espaços para que, em certa medida - não completamente determinante - relações sociais já instituídas, pautadas por certo conservadorismo, se manifestassem nas formas de controle social e gestão institucional de parcela da população identificada como pobre.

Analisar o desenvolvimento desta lógica permite construir uma explicação sobre como foi possível avançar socialmente sem alterar concepções estruturantes em torno da fome e da pobreza.

A análise desse conjunto de relações, permitiu evidenciar que o PBF representou a reorganização institucional dos programas sociais existentes à época de sua criação. E que esta foi a opção política feita em adequação e detrimento de outras possibilidades de ordenação das estruturas e práticas sociais.

Deste modo, num primeiro momento, este artigo se detém nas práticas e programas sócio assistenciais ao longo dos anos da década de 1990. Neste período, é possível notar como ações filantrópicas e solidárias, destinadas aos 
trabalhadores empobrecidos foram geridas em meio a um contexto que pretendia ordenar diferentes formatos para os programas sociais, alinhando-os às políticas macroeconômicas.

Essas ações ocorreram no que estava dado como um grande terreno, fertilizado por aspectos da filantropia e suas relações com ativistas e militantes, adubado por um tipo de solidariedade expressa como ato social e que havia sido materializada nas conquistas da Constituição Federal de 1988. Entretanto, essa concepção de solidariedade foi transviada pela tentativa de espremer em um canto a participação popular e dar mais espaço à uma economia Real.

Num segundo momento, analisa-se a elaboração e implementação do PBF. Este é um processo demarcado por rupturas políticas e pela consolidação de ações dirigidas aos trabalhadores empobrecidos, estas últimas, como o cerne das políticas sociais e como marca do próprio governo. As ações analisadas localizam-se entre os anos de 2003 e 2014. Interessa evidenciar quais foram as decisões políticas e as formas de identificação colocadas para as relações sociais que trilharam mudanças nas concepções de igualdade social e nos valores sociais.

Nesse período, a solidariedade foi um importante valor de mobilização e de leitura do social - dos interesses e expectativas sociais - que permitiu a centralização técnica do controle social. O discurso de eficiência da gestão institucional e do gasto público foi relacionado à cidadania e à solidariedade de uma forma que não é nem completamente diferente, tampouco igual ao que havia sido feito nos anos da década de 1990. Por fim, retomo alguns dos pontos abordados nas seções prévias e apresento algumas considerações sobre os mecanismos culturais e sociais que conferem legitimidade aos programas sociais.

1990: solidariedade, participação popular e pobreza frente a uma economia Real 
Os anos iniciais da década de 1990, demarcam o processo histórico de dissolução e rearranjo das então recentes conquistas de direitos sociais, materializados na Constituição Federal de 1988, aprovada, como se sabe, após a experiência social moldada pelos longos anos de ditadura militar.

Como registrou Gusmão (2000: 95), os princípios da Constituição de 1988 estavam imbuídos da ideia de solidariedade, estes, no entanto: "foram profundamente atingidos pela lógica neoliberal, que elegeu o mercado como regulador das necessidades sociais".

Nesse sentido, a solidariedade social como valor moral e político, que é base de toda a ideia de segurança social (JORDÃO et. al., 2013) - e que poderia levar adiante uma expressão de confronto e de oposição - cumpriu importante papel ao ser traduzida em ações governamentais para tratar as questões da fome e da pobreza.

Em meio às mobilizações da Campanha da Ação da Cidadania contra a Fome, a Miséria e Pela Vida; a divulgação do "Mapa da Fome" pelo Instituto de Pesquisa Econômica Aplicada (IPEA), a instalação do Conselho de Segurança Alimentar (CONSEA) - pelo governo de Itamar Franco, em 1993, e as discussões no interior do Instituto Cidadania, do PT, a "pobreza" voltou à cena nos anos de 1990, mobilizada pelos significados da solidariedade.

Portanto, uma solidariedade utilizada enquanto categoria de mobilização política centrada no apelo individual, e que organizou grupos e interesses em um sentido diverso daquele que buscava explicitar os antagonismos entre classes; como mediação e urgência. Aliada ao discurso de estabilidade econômica e política, o sentido da solidariedade enquanto categoria política, seria rapidamente furtado do que ainda tinha de transformador e universal.

A chave de leitura para este contexto consiste em notar que núcleos maiores ou menores de ideias e propostas, amalgamadas como os elementos centrais do PBF, circulavam na teia social e política entre os anos de 1990 e 2001: formulação de políticas sociais; propostas de mecanismos de transferência de renda; intervenção no núcleo familiar de trabalhadores empobrecidos e; as condicionalidades. Estes núcleos, foram sendo adequados à 
uma conjuntura de intensificação da exploração do trabalho, do aumento do número de trabalhadores pobres e da proposição de programas para a assistência social. Questões relacionadas a composição das famílias de trabalhadores, solidariedade, cidadania e mobilização política evocaram papéis diferentes ao longo dos anos de 1990. Estes papéis foram, de certa forma, materializados no corpo de gestão institucional e das condicionalidades para o controle social - ou de classes, pelo PBF.

É a partir deste enfoque que se pode evidenciar o encadeamento de um movimento social e político que configurou uma ampla gama de iniciativas da sociedade civil, de movimentos sociais, entidades filantrópicas e ações institucionais. Este movimento, está inserido em uma conjuntura que, de acordo com Gohn (1996: 29-30 e 34), representou para as "forças políticas do país" um momento de "trégua, um pacto de manutenção das regras mínimas democráticas" após o impeachment de Fernando Collor de Mello, com a “expectativa de uma transição gradual até 1994" quando ocorreriam novas eleições.

Nesse ínterim, reivindicações por direitos sociais foram traduzidas na relação com o Estado, esta foi intermediada por agentes como Herbet José de Souza, o Betinho ${ }^{4}$ através de ONGs e da Campanha da Ação da Cidadania. Este processo de intermediação impôs uma linguagem que associou fome e miséria na dimensão de que um certo tipo de contratualidade vigoraria entre Estado, entidades e atendidos. A fundação do PT - junto à articulação com os movimentos sociais - também havia ampliado o espaço de diálogo público a

\footnotetext{
${ }^{4}$ O sociólogo Herbert de Souza, o Betinho, fundou o Ibase em 1981 e, na década de 1990, tornou-se símbolo de cidadania no Brasil ao liderar a campanha contra a fome. (...) Em 1992, fez parte do Movimento pela Ética na Política, que culminou com o impeachment do então presidente Fernando Collor de Mello. O movimento serviria de base para a mobilização da campanha contra a fome. (...) Betinho resistiu ao golpe de 1964 e à ditadura que se instalou no Brasil. Quando a repressão intensificou- se, partiu para o exílio em 1971. (...) Betinho retornaria ao Brasil em 79 e criaria dois anos depois, junto com os companheiros de exílio Carlos Afonso e Marcos Arruda, o Ibase. (...) Em 2012, a história de Betinho foi reconhecida pela Unesco como parte importante da memória mundial. (...). IBASE. Betinho símbolo de cidadania. Disponível em: < http://www.ibase.br/pt/perfil-betinho/>. Acesso em 14 set. de 2014.
} 
partir de seu papel como catalisador das disputas pela concretização dos direitos sociais.

De acordo com Gohn (1996), a "Carta da Ação da Cidadania: democracia e miséria não são compatíveis", documento base da Campanha, elenca a miséria como seu principal elemento articulador. Na leitura da autora, a personalização da Campanha em Betinho decorreu de "um esforço para caracterizá-la exclusivamente como uma ação da sociedade civil", nesse sentido, "o próprio Betinho" teria atuado para relacionar "a origem da Ação da Cidadania exclusivamente ao Movimento pela Ética na Política, ${ }^{5}$ deixando de lado a participação inicial da sociedade política", ou seja, isolando da campanha a influência do PT que era forte tanto no cenário eleitoral quanto no de oposição ao governo de Itamar Franco. ${ }^{6}$

Em um curto espaço de tempo, a miséria, como mote, será deslocada e unificada na pauta do combate à fome. Assim, sob as frases "quem tem fome tem pressa" ou "quem tem fome não pode esperar" a Campanha foi orientada pelo impacto dos dados divulgados pelo Mapa da Fome e utilizou-se de comitês locais para a distribuição de alimentos, além de chamar os empresários para a contribuição ativa.

De acordo com Gohn (1996: 31), com a organização da Campanha, ocorreu uma importante mudança naquilo que antes conferia algum tipo de unidade às articulações que existiam entre os movimentos sociais "desde os anos 70" que era o "político-partidário, ou [o] político-ideológico" como forma de compor a "articulação ou participação em movimentos sociais". Alinhada à ideia de pacto democrático então em vigor, na avaliação de Betinho: “A Ação da Cidadania reúne pessoas das mais diferentes origens políticas, ideológicas, sociais e econômicas", de modo que "a solidariedade, antes somente teórica, passa a ser praticada" (ENTREVISTA, 1993). Nesse sentido, cabe notar que

\footnotetext{
${ }^{5}$ A Campanha da Ação da Cidadania foi organizada utilizando-se das estruturas do Movimento Pela Ética na Política (MEP), de 1992, que foi organizado em núcleos com grande capilaridade pelo país para levar adiante o processo de reivindicação pelo impeachment de Fernando Collor de Mello.

${ }^{6}$ Itamar Franco foi o vice-presidente de Fernando Collor de Mello (1990-1992) e assumiu a Presidência pelo período entre 1992-1995, após o impeachment de Collor.
} 
duas das três singularidades do primeiro comitê da campanha no Rio de Janeiro, e que marcaram seu perfil apartidário, foram a participação de "entidades públicas, especialmente do setor bancário; e a heterogeneidade de entidades" (GOHN, 1996: 31).

Em balanço realizado por Pinto, a autora destaca que o modelo descentralizado da Campanha contribuiu para o desperdício e para a não racionalização da distribuição das cestas básicas arrecadadas e que, apesar de nunca ter oficialmente acabado, as ações foram descontinuadas em grande escala. Para a autora, "os brasileiros com fome continuaram na mesma situação, após um ano de campanha" e, os efeitos levados a cabo pela ação, como o exercício de cidadania, foi proporcionado somente aos grupos já incluídos" (PINTO, 2005: 209-210 e 222). Na avaliação de Rocha (2013: p. 80), a despeito dos objetivos de "solidariedade e justiça social" estarem presentes, a campanha foi marcada pela urgência do tema e resultou em ações de "caráter predominantemente filantrópico".

Esse contexto evidencia um aprendizado político que é essencial à compreensão dos programas sociais que serão forjados ainda na década de 1990 e que serão reorganizados nos anos 2000. As ações empregadas no sentido da promoção da solidariedade como instrumento de combate à fome e como forma de organização para fins de uma suposta transformação estrutural, passam a ser refletir os impasses e disputas relacionados a formulação de pautas aglutinadoras. Como analisa Gohn, a Campanha se destacou de outras ocorridas no Brasil ao longo do século XX por várias características, dentre elas, tratavase "de uma campanha nomeada, com um 'pai': Herbert de Souza, o Betinho' (GOHN, 1996: 54).

\footnotetext{
${ }^{7} \mathrm{~A}$ atuação de entidades públicas e do setor bancário, em meio às mobilizações de associações de moradores e trabalhadores empobrecidos, evidencia o descolamento entre as dimensões do trabalho e dos direitos sociais fundados na solidariedade enquanto ato social. São muitas as ações expressas na ressignificação de um tipo de controle social que moldaria quais ações à população empobrecida seriam aceitáveis em meio à manutenção de certo status político. Esses elementos foram notados a partir de experiências políticas na cidade de Uberlândia (MG) em estreita relação com o cenário nacional. Abordo essa discussão no "Cap. 3 Trabalho e Pobreza: Antagonismo e conciliação" em De Sordi, 2019.
} 
Há, no processo de estabilização e arrefecimento da Ação da Cidadania, uma permanente tensão entre caminhos de mobilização da sociedade civil voluntarista - e soluções políticas de iniciativas no campo da política de governo - intermediadas por movimentos sociais organizados que chamem a sociedade civil à ação. Esta característica permanecerá nos anos 2000, como uma das preocupações quanto ao formato e identidade dos programas que serão desenvolvidos durante o governo Lula.

Nesse sentido, as narrativas do período, em torno das pautas por uma política social e pela continuidade da Ação da Cidadania guardam, em alguma medida, certo consenso em torno da ação coletiva, pois em geral, estão circunscritas nas relações entre o Instituto de Pesquisa Econômica Aplicada (IPEA) com a divulgação do "Mapa da Fome"" e o Instituto Cidadania, com a figura de Lula como intermediador da ponte entre ação social - baseada no plano de Segurança Alimentar e Nutricional (SAN), do PT - e o governo de Itamar Franco.

Representativo desta questão é o fato de o projeto de SAN, apresentado pelo PT a Franco, ter também impulsionado a criação do CONSEA, o que indica um ato significativo de ação para a manutenção estrutural articulada ao largo do campo popular, porém com o respaldo da Campanha da Ação da Cidadania. A Ação da Cidadania foi articulada num espaço de reivindicação pela promoção de uma política pública, portanto, pronunciada com bases na mobilização da sociedade civil com a atuação conjunta de articulações políticas (PINTO, 2005: 208-209). Na literatura que aborda essas mobilizações, há a tendência a apontar dois caminhos diferentes como precursores da mobilização social e institucional que provocaram a instalação do CONSEA por Franco. Sendo que uma destaca o engajamento do PT, ao passo que a outra preserva o

\footnotetext{
${ }^{8}$ As controvérsias em torno da metodologia do Mapa da Fome que suscitaram questionamentos acerca dos dados apresentados são abordadas em PELIANO, Anna Maria Medeiros. Lições da História - avanços e retrocessos na trajetória das políticas públicas de combate à fome e à pobreza no Brasil. In: Fome Zero: Uma História Brasileira. Org.: Adriana Veiga Aranha. Brasília, DF: Ministério do Desenvolvimento Social e Combate à Fome, Assessoria Fome Zero, v. 1, 2010. pp. 26-40.
} 
foco na figura de Betinho e na expressão social da solidariedade como protagonistas dessa conjuntura.

É possível indicar, que os objetivos do CONSEA contemplaram, ainda que em partes, algumas das medidas que foram propostas para a área social no documento de 1992 intitulado "O Partido dos Trabalhadores, o Impeachment de Collor de Mello e o governo Itamar Franco". Seu conteúdo programático e reivindicatório tinha por objetivo propor alternativas de gestão para o governo de Franco. De acordo com Martuscelli, os pontos programáticos propostos perdiam sua operacionalidade em meio ao cenário político no qual, "a correlação de forças políticas, engendrada pelo próprio movimento próimpeachment, limitou a ação das lutas sociais à sustentação da legalidade burguesa" (2010: 563-564). Em diálogo com o autor, é possível indicar, que esse tipo de postura propositiva aparecia de forma ambígua no campo petista. Frente ao cenário eleitoral que estava no horizonte, e a pressão pelo enfrentamento dos efeitos de medidas neoliberais. Nesse ínterim, cabe notar, que o projeto de SAN do PT esteve presente, como registrou Carlos Alberto Libanio Christo - conhecido como Frei Betto - nas campanhas concorridas por Lula nos anos de 1994, 1998 e 2002 (BETTO, 2010: 133).

É certo que houve uma confluência de interesses e pautas nas mobilizações entre as várias frentes de oposição ao governo que trabalharam a questão da fome. Em meio às interpretações sobre os projetos elaborados pelo Instituto Cidadania, ${ }^{9}$ é importante notar que há um tipo de avaliação realizada nos anos 2000, que enquadra a ação de Lula como catalisadora da temática da fome e do impulso para a criação das ações do período:

Em 1991, como resultado do trabalho realizado pelo chamado "governo paralelo", então liderado por Luiz Inácio Lula da Silva, enquanto alternativa ao governo de Collor de Melo, foi elaborada uma proposta de Política de Segurança Alimentar. Esta foi entregue dois anos depois ao novo

\footnotetext{
${ }^{9}$ O Instituto Cidadania emerge da composição do Governo Paralelo do PT em 1990 que foi inspirado no shadow cabinet inglês, formado logo após a vitória presidencial de Fernando Collor de Mello, em 1989. Com o impeachment de Collor, em 1992, o Instituto Cidadania é direcionado para estudos de temas ligados às questões nacionais, dentre elas, a fome. Foi transformado no Instituto Lula em 2011.
} 
presidente Itamar Franco, que tomara posse diante do impeachment de Collor. Nela, já estava prevista a criação do Conselho Nacional de Segurança Alimentar - CONSEA, como de fato ocorreu em maio de 1993. Esta proposta do "governo paralelo", que incluía a criação do CONSEA, coincidiu com toda uma movimentação que se iniciou na sociedade, como desdobramento do Movimento pela Ética na Política, de mobilização contra a fome. Inicia-se, então, a chamada Campanha contra a Fome, liderada pela Ação da Cidadania (...). (MENEZES, 2010: 121)

De qualquer forma, o impacto da instalação do CONSEA por Itamar Franco pode ser medido por ter colocado a fome na agenda política nacional. Esta era uma pauta que previa impulsionar o debate de questões interligadas ao conceito de Segurança Alimentar, tais como: “(...) a relação Estado-sociedade, ações locais de cidadania, a questão agrária e o desenvolvimento rural, política agrícola, saúde, educação, geração de empregos e políticas de renda" (TELLES, 2013: 153). Entretanto, apesar da ampla gama de ações previstas, o que se consolidou, de acordo com avaliação de Peliano (2010: 35-36) foi que o mote da fome, incorporado pelas ações do CONSEA, na prática, sobressaiu-se. Rocha (2013: 80) pontua que isso se deve ao fato de que o debate "do acesso aos alimentos pelos mais pobres no início dos anos 1990 tinha marcado profundamente a opinião pública".

A partir do início do mandato de Fernando Henrique Cardoso, em 1995, o tema da fome enquanto veículo de organização política e questão nacional urgente, permaneceu em subterrâneo na pauta política, sombreado pelo desenvolvimento de programas sociais organizados por uma ideia de solidariedade distante de sua potencialidade como ato social. A fome como categoria política, que poderia oferecer uma leitura às questões sociais brasileiras, só será retomada como ponto expressivo da agenda política nacional com a campanha e a eleição de Lula à presidência nos anos 2000. Porém, isso ocorrerá em outros termos, primeiro com o programa Fome Zero, e em seguida, alinhada ao combate à pobreza com o PBF.

Mapear essa discussão permite evidenciar que as estratégias da Campanha da Ação da Cidadania tiveram importante papel na reorganização 
das formas e valores para se fazer o combate à pobreza no país. O contexto de crise política e social em que ocorreu, com seu forte apelo à mobilização individual e às ações descentralizadas, a transformou, como captou Gohn, em um "modelo de ação social. E, como tal, foi copiada enquanto programa governamental, (...) no programa Comunidade Solidária” (1996: 23). Criado em substituição ao CONSEA, ${ }^{10}$ sob o mandato de FHC, o Programa Comunidade Solidária (PCS), sob a direção da antropóloga e primeira dama Ruth Corrêa Leite Cardoso, abriu caminhos para a materialização de um abundante "terceiro setor" (MONTAÑO, 2010).

O PCS significou a reformulação dos princípios que intencionavam articular a mobilização social nas temáticas da segurança alimentar e do combate à fome. Para Telles (2013:10), com o início do Plano Real ${ }^{11}$ e do governo de Cardoso ocorreu um "curto-circuito" nos processos organizados "desde baixo", de modo que a experiência dessa forma de organização política foi privada de sua potência organizativa e simbólica. E nesse sentido, debater a experiência do CONSEA, em oposição ao PCS, permite evidenciar "a erosão das referências cognitivas e valorativas pelas quais as noções de bem público e reponsabilidade pública poderiam ser formuladas como horizonte possível" (TELLES, 2013:10).

Cabe notar, que apesar dos diversos avanços nos índices econômicos e sociais, estes permaneceram modestos frente aos danos causados pela política macroeconômica levada a cabo por Cardoso (ANDERSON, 2002: 18-19). A ideia de eficiência no gasto público foi enunciada como uma marca do governo

\footnotetext{
${ }^{10}$ Vale notar que junto com o CONSEA foi extinta a Legião Brasileira de Assistência (LBA), o Ministério do Bem-Estar Social (MBES) e o Centro Brasileiro pra a Infância e a Adolescência (CBIA) ao passo que, para fins da assistência social, foi criada a Secretaria de Assistência Social do Ministério da Previdência e Assistência Social (SAS/MPAS) (PERES, 2005).

${ }^{11}$ Como apontado por Eurelino Coelho, foi no governo de Franco, sob o Ministério da Fazenda, que uma das formas de instituição da hegemonia burguesa no governo de Cardoso teria se iniciado. Na avaliação do autor: "O Plano Real, mais do que um plano de estabilização monetária, foi a construção de um instrumento político de hegemonia que habilitou um grupo político a pleitear o comando dos interesses gerais do país". Para Coelho, "embora a crise econômica tenha se aprofundado, a década de 90 alterou profundamente a correlação de forças em favor da burguesia no Brasil". Teria ocorrido a construção de um "consenso produzido em torno do governo FHC [que] foi tanto uma expressão quanto um mecanismo de construção desta nova hegemonia". (COELHO, 2005: 442).
} 
de Cardoso, e estava contida no projeto de reformas do Estado encaminhadas pelo Ministério da Administração Federal e Reforma do Estado (MARE). ${ }^{12}$ Neste contexto, políticas sociais foram transformadas em entidades públicas não-estatais (PERES, 2005: 117). À margem da Lei Orgânica de Assistência Social (LOAS), os projetos do PCS foram voltados amplamente para o envolvimento de empresas e instituições privadas no gerenciamento e financiamento das ações estruturantes das políticas sociais. O PCS teve "como estratégia central a articulação em torno de quatro grandes princípios: parceria, solidariedade, descentralização e integração e convergência de ações" (RESENDE, 2000: 4).

O deslocamento da responsabilidade coletiva para a responsabilidade individual atendeu a um dos termos das políticas neoliberais por meio das quais "o capital, assim, se desonera da contribuição compulsória", de modo que, "sua intervenção na 'ação social' assume a forma voluntária de 'doação'- segundo sua 'consciência cidadã' e sua 'responsabilidade social'-, não de obrigação" (MONTAÑO, 2010: 236). Nesse sentido, há uma redefinicação das possibilidades para o exercício da solidariedade social e da cidadania. As mudanças quanto ao sentido do doar passam a ser formalmente operadas no

\footnotetext{
${ }^{12}$ A Reforma do Estado no governo de Fernando Henrique Cardoso foi realizada nos preceitos do Consenso de Washington e guiada por Bresser Pereira no MARE. De acordo com Montaño, a reforma era composta por três dimensões: "Uma dimensão primordial que é institucionallegal, baseada na criação de instituições normativas e organizacionais, como agências executivas e organizações sociais, que constituem unidades descentralizadas de gestão. Uma segunda dimensão cultural, baseada na mudança dos valores burocráticos para os gerenciais. Uma última dimensão-gestão, para pôr em prática as novas ideias gerenciais (...)". Pereira, regido por tais critérios gerenciais, preferia o "cidadão-cliente" de serviços ao "cidadãousuário" de direitos, pois o critério do primeiro seria o melhor atendimento ao "cidadão-cliente" a um custo menor". Para Montaño, a despeito do discurso com ares de inovação de Pereira frente ao suposto e alardeado engessamento burocrático da Constituição de 1988 -, as propostas de reforma do então ministro: "mostram claramente a continuidade do ajuste fiscal e a subordinação da reforma gerencial às necessidades econômicas e financeiras deste ajuste. Estamos, portanto, frente a um programa de "reforma administrativa" que se depreende da política econômica e nela se insere. Longe de se tratar de uma 'reforma técnica', ela é política e subordinada às questões econômicas. Trata-se de readequar a Constituição brasileira aos ditames do grande capital, de subordinar a Constituição de 88 aos ditames do FMI, BM, OMC e aos postulados do Consenso de Washington. Como afirma Netto [1999] (p. 80), 'esta orientação tomou corpo na política econômica de FHC: ele fez do 'Plano Real', como instrumento de estabilização monetária, o primeiro passo para uma inteira abertura do mercado brasileiro [...] ao capital internacional', articulada à reforma do Estado, que lhe retirava parcialmente o papel empresarial (via privatização) e que reduzia os fundos públicos para o financiamento das políticas sociais." (marcações em itálico do autor). MONTAÑO, 2010: 42 e pp. 44-45.
} 
escopo do discurso da parceria entre o Estado e o voluntarismo. Instala-se a compreensão de que o doar precisa gerar um resultado economicamente eficaz e alinhado à responsabilização individual. Que, portanto, condicione tanto as formas de se sentir contemplado pelos direitos sociais, focalizados, quanto os modos pelos quais as condições materiais de vida serão geridas e reproduzidas no equilíbrio da regulação das dinâmicas sociais.

Esse processo descaracterizou as formas de mediação social, pois os direitos assim postos, "não têm como ser formulados, não têm como ser reivindicados e são privados das mediações pelas quais o litígio pode ser configurado" (TELLES, 2013: 161) A erosão dos direitos sociais, não mais localizados na dimensão do trabalho, põe de lado o entendimento de que "os cidadãos só podem exigir seus direitos à saúde, à educação, à alimentação ao Estado", a importância deste debate está em reconhecer que "a política pública tem um princípio de igualdade e universalidade que não faz parte da natureza" (PINTO, 2005: 199) das ações que foram empreendidas pelo PCS.

Apesar da presença de termos como solidariedade, e os objetivos de lidar com dimensões específicas da condição de pobreza, o PCS e demais programas $^{13}$ que demarcam a segunda metade dos anos da década de 1990 impulsionaram um tipo de solidariedade específico, não coletivo, mas individualizante que suplantou o horizonte de mudanças sociais previstas com a Constituição de 1988. Evidenciar este processo histórico permite notar as particularidades dos postulados neoliberais no contexto brasileiro. Estes reorganizaram as formas das relações sociais e as possibilidades que estavam

\footnotetext{
${ }^{13}$ Refiro-me aos programas que compuseram a Rede Social Brasileira de Proteção Social, dentre eles, o Programa de Erradicação do Trabalho Infantil (PETI), criado em 1996 e inicialmente aplicado em áreas com maior incidência de trabalho infantil, expandido para o país todo em 1999; O Programa Bolsa Escola e o Programa Bolsa Alimentação, ambos de 2001, o Programa Auxílio Gás, criado em 2002 frente ao fim do subsídio do botijão de gás. O Auxílio Gás foi o primeiro destes programas a ser ofertado a toda uma população pobre definida pelo critério de renda, o que inaugura o que se consolidou como o caráter universal à uma parcela da população no PBF (ROCHA, 2010:71). Esta Rede abrangia diversas ações com o objetivo de combater a pobreza enquanto um fenômeno multisetorial. Tal fator abriria espaço ainda para o deslocamento das dimensões da reprodução social. No campo dos programas assistenciais, isso significou que para cada "setor" desenvolveu-se um programa específico - como tematização da questão social - não necessariamente relacionados entre si em sua gestão.
} 
no horizonte de discussões políticas para o enfrentamento de baixas condições materiais de vida. Nesse sentido, cabe destacar o que pontua Oliveira:

\begin{abstract}
A caracterização do ciclo neoliberal não reside apenas, nem exclusivamente, nas formas e opções da política econômica geralmente conservadora sob a égide de políticas monetárias recessivas e políticas fiscais ortodoxas. Talvez seja no plano social que o neoliberalismo fique marcado como um período único na moderna história brasileira, na história de média duração, desde 1930. De fato, é a política antirreformas sociais, antirregulacionista, antidireitos do trabalho e direitos sociais em geral que marca o neoliberalismo. (2018: 66)
\end{abstract}

Com a transmutação dos espaços públicos de gestão social para o corpo do associativismo e do voluntarismo, a ação coletiva voltou assim à esfera da consciência individual - do ponto de onde tinha parado; que é antes do período que Oliveira (2007) denomina como de reinvenção política entre os anos de 1978-1988.

Como argumentou Sader (1988), foi nas décadas dos anos de 1970 e 1980 que as condições de vida da população empobrecida entraram no debate público brasileiro, a partir, não apenas da mobilização voluntariosa de agentes políticos, mas, principalmente pela mobilização de sujeitos nas periferias, organizados em associações para reivindicar acesso e melhorias aos serviços públicos, à direitos e ao poder de decisão política. No contexto deste período, o tema da "pobreza" teria sido retirado de cena, abrindo espaço e atenção à ação coletiva. No entanto, nos anos de 1990, como nota Oliveira (2007), a "pobreza" volta à cena enquanto uma "categoria política" (SINGER, 2018: 18) no contexto de consolidação e ampliação da democracia.

Desta forma, "pobreza" será a expressão da leitura de uma pauta que individualiza e reorganiza as possibilidades de organização e mobilização pública, isto é, social, pois está dissociada de sua relação intrínseca com os mecanismos de expropriação e exploração. Portanto, está pautada por uma leitura que compreende a desresponsabilização do Estado em relação às questões sociais, e que só pode ser compreendida em "sua articulação com a autoresponsabilização dos sujeitos carenciados e com a desoneração do 
capital na intervenção social, no contexto do novo projeto neoliberal" (MONTAÑO, 2010: 234-235).

Ainda que ao longo dos anos da década de 1990, houvessem leituras dissonantes nas quais a superação das condições de pobreza fosse lida de forma atrelada a uma série de condições externas ao controle dos trabalhadores, ${ }^{14}$ tais leituras, de certa forma, se dissolvem com a mudança do cenário político para os programas sociais no início dos anos 2000, com a nacionalização de experiências locais de programas sociais.

Nesse sentido, a perspectiva de aprofundamento de uma leitura de responsabilização individual deriva da inserção de programas sociais de transferência condicionada de renda como instrumento para lidar com o combate à pobreza. Esta inserção foi pautada por um debate que se adensa em meados da década de 1990, e que era inspirado na ideia de uma Renda Básica de Cidadania. ${ }^{15}$ No entanto, em 2001, com a nacionalização do programa Bolsa Escola, ao invés da Renda Básica de Cidadania, a opção política foi em favor do modelo dos programas de Renda Mínima, direcionados a um público específico, focalizados e com a cobrança de contrapartidas - conhecidas como condicionalidades a partir do PBF - por parte das famílias atendidas.

A condição de acesso ao ensino formal foi incorporada como instrumento de intermediação para a transferência de renda e como argumento de que seria preciso incutir determinado valores nas famílias atendidas pelos programas sociais para que elas, de fato, pudessem "melhorar de vida" com a promoção da "cidadania" e da "dignidade". Ainda em 2001, o Cadastro Único para Programas do Governo Federal (CadÚnico) passa a ter que, obrigatoriamente, compor a base informacional dos programas sociais. Estas duas características permaneceriam no corpo do PBF como expressões das

\footnotetext{
${ }^{14}$ Realizo esta discussão de forma mais detida na seção "1.2 - Solidariedade transviada: participação popular e econômica Real não combinam" em De Sordi, 2020. Analiso os programas de governo do PT e do PSDB para as campanhas presidenciais de 1990 observando os diferentes repertórios políticos disponíveis para a implementação de direitos sociais em uma mesma ambiência política.

${ }^{15}$ Sobre o projeto de Renda Básica de E. M. Suplicy (PT) e os debates que encaminharam o Renda Mínima como modelo Cf. seção 1.3 - "Uma utopia realista": Renda básica ou renda mínima em De Sordi, 2020.
} 
condicionalidades e de um controle social em sentido diverso do previsto como de gestão democrática.

Nessa trama, é a partir do ciclo de supostas incapacidade e desinteresse ligado à teoria de desenvolvimento do capital humano (MAURIEL, 2004: 223), que a pobreza é vista enquanto fenômeno "inevitável", quanto ao qual "nada existe a ser feito além da gestão da miséria para minorar seus efeitos" (TELLES, 2013: 158). O espaço de atuação institucional, por esta via, está nos trabalhadores empobrecidos. A figura do "pobre" emerge, portanto, como constructo social a partir da "dualização entre trabalhadores integrados nos circuitos modernos da economia e os 'pobres' assistidos por programas sociais" (TELLES, 2013: 158).

Evidenciar a qualificação da "pobreza" enquanto categoria política ao longo dos anos de 1990, permite notar a tendência de esgotamento das vias institucionais para a concretização de uma cidadania ativa, transformadora e ampliada. Esta era uma possibilidade que foi matizada pela vigilância e pela racionalidade técnica, que, ao ser aplicada como técnica social, teve por objetivo: "modelar o comportamento social e as relações sociais" (MAURIEL, 2008: 23). Das dimensões da fome, do analfabetismo e da pobreza como responsabilidades coletivas e políticas, a intervenção deixa de ser social e passa à esfera individual, privada. A cidadania é assim, circunscrita à capacidade de encaminhamento das questões sociais e coletivas pela esfera das possibilidades individuais. É justamente pela necessidade relacional que a prática voluntária estabelece que os sujeitos serão integrados às políticas sociais, a concepção de direitos sociais é esvaziada. Este é um processo que se expressa na propagação de um tipo de desenvolvimento econômico que "legitima a exclusão como forma de integração" (GOHN, 1997: 236).

\section{Programa Bolsa Família: Conciliação e controle}

A afirmação de Lula de que "a fome não produz revolucionários, produz pedintes" (SOUSA, 2010: 109) é significativa para a compreensão de como as 
experiências de mobilização política dos anos da década de 1990 confluíram na ordenação das possibilidades que constituíram o substrato que organizou o PBF. Os programas sociais anteriores, então aliados à prioridade do desenvolvimento econômico, tiveram grande peso na estruturação dos programas sociais petistas, mediados pelo controle dos antagonismos entre classes.

Apesar da imagem autônoma que atingiu desde que veio a público com sua regulamentação em setembro de 2004, o PBF deve ser localizado como uma ação de um dos eixos do que se tornou a "Estratégia" Fome Zero. O lançamento do PBF, no âmbito do Fome Zero, ${ }^{16}$ recebeu destaque por ter unificado os programas sociais nacionais de Renda Mínima vinculada à educação "Bolsa Escola" (2001), o Renda Mínima vinculado à saúde "Bolsa Alimentação" (2001) e o "Auxílio Gás" (2002) - gestados durante o governo de Cardoso - e, o programa de Acesso à Alimentação "Cartão Alimentação" criado como uma das ações do Fome Zero em 2003, no início do governo Lula.

De acordo com o próprio Lula, a partir da unificação destes programas, o Programa Bolsa Família tornou-se a iniciativa mais conhecida e notada dentre todas as do Fome Zero (SILVA, 2010). É preciso pontuar que o lançamento do PBF se deu em meio a um anunciado rompimento dos quadros do PT com seu governo, dentre outros motivos, devido aos rumos das políticas sociais e a diminuição do espaço de possibilidades para a participação popular. Tais motivos indicam a cidadania formulada que acabaria por se tornar característica desse governo.

Cabe notar, que em janeiro de 2003, o Fome Zero foi destaque no discurso de posse à presidência da República de Lula quando conclamou a sociedade a tomar o fim da fome como "uma grande causa nacional, como foram no passado a criação da Petrobrás e a memorável luta pela

\footnotetext{
${ }^{16}$ O Fome Zero foi inaugurado em 2001 como um projeto, adquirindo o status de programa em 2003 e de estratégia em 2005, de modo que o PBF está localizado em um conjunto ampliado de ações (SILVA; TAVARES, 2010: 235). É possível avaliar que tais mudanças em seu status tem muito a ver com a transformação nas formas de gestão do programa, compreendidas no contexto de incompatibilidade entre a organização popular e as metas do governo: entre um governo transformador e um governo reformista.
} 
redemocratização do país (...) uma luta de todos sem distinção de classe, partido, ideologia" (BRASIL, 2013).

Entretanto, após o lançamento do PBF, o Fome Zero foi, na prática, varrido das discussões sobre o Bolsa Família. A análise da bibliografia e fontes produzidas entre 2003 e 2010 permitiu evidenciar que a própria narrativa sobre o Fome Zero, enquanto um programa social, pode ser identificada a partir de campos de "tendências" para o debate. De modo que, em resumo, exemplificam: 1) o PBF como desdobramento e ajuste do Fome Zero em prol da eficiência de gestão e do controle social. Esta é uma linha mais frequente em narrativas institucionais, pelo menos até 2010. A partir do decênio do PBF, as discussões centram-se em seus próprios objetivos e metas; 2) mais recorrente em estudos da área econômica e da assistência social que analisa os impactos da transferência condicionada de renda, o Fome Zero é notado a partir da incorporação ao PBF do público que era atendido pelo "Catão Alimentação". Por esta via o PBF é apresentado como correção para as questões em torno do controle social versus fiscalização previstos no Fome Zero; 3) Por fim, mais recorrente em relatos e avaliações dos atores que compunham os quadros do governo, o PBF é lido em substituição completa ao Fome Zero, não há por esta perspectiva, desdobramento natural ou correção dos méritos e possibilidades do Fome Zero, aqui, pelo contrário, o PBF é sinônimo da guinada neoliberal do projeto petista.

Desde sua implementação, o PBF sofreu alterações no que diz respeito aos seus instrumentos de articulação e fiscalização - definidos, dentre outros, pelo Índice de Gestão Descentralizada (IGD) - e da variação dos benefícios em seus tipos e valores. Um passo considerado significativo foi a articulação do programa com o SUAS (Sistema Único de Assistência Social), implementado em 2005. Porém, os objetivos instituídos para o PBF permaneceram; sendo o imediato transferir renda diretamente às pessoas selecionadas por faixa de renda per capita familiar como extremamente pobres ou pobres - a partir de um corte de renda que variou ao longo dos anos - e instar o acesso a direitos através de condicionalidades nas áreas de saúde, educação e assistência social. 
Enquanto um programa de alívio imediato de privações materiais básicas, ao ser articulado com ações da assistência social, objetiva em longo prazo o estímulo ao desenvolvimento das famílias beneficiárias, com a interrupção do ciclo intergeracional da pobreza. Na avaliação de Campello:

Com o Bolsa Família, o Brasil pôde, enfim, recusar a banalização e naturalização da pobreza e da fome e afirmar um novo patamar de garantias sociais, que exigem o reconhecimento e o progressivo alargamento de padrões mínimos de bem-estar a todos os cidadãos. (2013: 19)

A ideia de um padrão mínimo de bem-estar a todos os cidadãos é questionável dentro dos limites do próprio $\mathrm{PBF}$, enquanto um programa de complementariedade da renda que busca minorar os efeitos e riscos sociais da pobreza. Não tem como objetivo a erradicação da pobreza, ou a completa responsabilização do Estado por esse fenômeno que é decorrente da política econômica vigente. $\mathrm{O}$ bem-estar nas atuais políticas sociais, orientadas pelo PNUD, devem ser compreendidas em sua base que define a pobreza "como falta de dotação", e condiciona:

a elaboração das reformas nos sistemas protecionistas em todo o mundo por meio de uma 'nova geração de políticas sociais' que não têm como resultado um 'bem público', mas um 'bem individual', nem a função de produzir proteção social, mas auto-proteção individual. Sob esse prisma, justiça social também adquire outro significado: o de oportunizar a todos se capacitar, se auto-cuidar e se inserir no mercado. (MAURIEL, 2008: 166)

O Programa foi formulado em diálogo, principalmente, com o suporte técnico dos organismos que integram o World Bank - enquanto experiência de um "modelo" desse tipo de programa para outros países. O contrato entre o banco e o governo foi focado na "avaliação, monitoramento, cadastro único e fortalecimento institucional", de modo que não haveriam contrapartidas visto que o aporte dispendido e orçado seria de dez por cento pelo banco, sendo a outra parte, de noventa por cento, pelo próprio governo. A avaliação para este arranjo consistiu na ideia de que: "ao condicionar o dinheiro a gastos com 
educação e saúde, é uma transferência pensando no futuro. Ele atende também a pobreza do amanhã" (MURPHY, 2003).

Nesse sentido, depreende-se que o objetivo do PBF de interrupção do ciclo intergeracional de pobreza tem relação com o deslocamento em torno de certo entendimento econômico que associava o bem-estar ao trabalho, e que passa a utilizar a figura do pobre como significante da categoria política da pobreza. Faz-se necessário, portanto, um "incentivo" para atingir a "autosuficiência", desviando-se da dependência do Estado e combatendo possíveis problemas decorrentes da estrutura familiar. A própria nomenclatura de "beneficiário", evidencia que nas políticas sociais atuais, em um cenário global, "a cidadania é percebida como dotação de determinados status individuais (consumidor, civil etc.), e a justiça social se define pela ideia de aumento de liberdades e promoção das capacidades" (MAURIEL, 2008: 208).

Há um debate teórico realizado principalmente pelas ciências política e social - em torno das escolhas políticas que trilharam esse caminho institucional, aberto não somente pelo que fez o governo de Lula, suas características principais, mas pelas expectativas em torno do que se julga que deveria ter sido esse governo, onde a solidariedade foi politicamente qualificada e, ao longo de dois mandatos, pode-se dizer, personalizada no próprio Lula em seu “carisma pop" (AB'SABER, 2016).

Coelho, em pesquisa na qual analisou a crise dos marxistas e do marxismo, dialoga com a teoria gramsciana e identifica um caso de transformismo dentre a esquerda brasileira. A hipótese central do autor é que o abandono do marxismo implicou em uma alteração da concepção de mundo de uma esquerda que, por uma radical mudança de direção, se deslocou no terreno da luta de classes. Coelho analisa essa modificação nos momentos particulares das dinâmicas das relações internas do PT, na constituição de seu campo majoritário com as viradas programáticas das quais resultou um peculiar ajuste que conciliou a relação entre o mercado e o Estado (COELHO, 2005).

Ab'Saber exemplifica o que ocorreu com o projeto do governo petista ao registrar que em determinado momento, às vésperas da eleição presidencial 
de 2006, os banqueiros eram indiferentes à eleição de Lula ou Alckmin (PSDB). Na avaliação do autor, esse "foi simplesmente o momento histórico em que o projeto político e econômico peessedebista original deixou de ter razão de existir" (AB'Saber, 2016: 19, grifos no original).

Por outra via, ao notar a dinâmica da capilaridade social do PT, para Singer (2012), a partir de 2003 a conjuntura econômica permitiu o crescimento econômico sem confronto com o capital, impulsionando a adoção de um amplo leque de políticas sociais com foco na redução da pobreza extrema. Para o autor, tais medidas, no contexto da crise do mensalão, teriam cristalizado um realinhamento eleitoral em 2006, para o qual a agenda de redução da pobreza foi primordial (SINGER, 2012: 13-15). Na análise de Singer, a configuração de uma nova divisão política brasileira da qual emergiu o lulismo, ${ }^{17}$ contou, em grande medida, com os impactos do PBF em "várias dimensões da existência da parcela mais pobre do Brasil, sem as quais, aliás, o fenômeno do realinhamento eleitoral não seria compreensível” (SINGER, 2012:63-69). A partir do lançamento do PBF em 2003 diversas pesquisas constataram "gradual melhora na condição de vida dos mais pobres", sendo registrada em 2005 a primeira queda significativa do quadro de miséria no país desde o Plano Real (SINGER, 2012: 135).

Ao analisar a adesão da tradicional classe média ao PSDB e seu afastamento do PT - o que permitiu a entrada dos pobres na base eleitoral petista - Singer aponta o realinhamento político e eleitoral materializado em 2006. ${ }^{18}$ Este, figura como uma síntese dos aspectos contraditórios centrais que

\footnotetext{
${ }^{17}$ Em síntese, "Lulismo" tem sido o termo corrente - cristalizado pela pesquisa de André Singer (Os sentidos do lulismo: reforma gradual e pacto conservador. $1^{\circ}$ ed. - São Paulo: Companhia das Letras, 2012) para descrever o fenômeno do realinhamento das bases eleitorais do PT após a chegada de Lula à Presidência quando ocorreu o desenvolvimento de um tipo de "reformismo fraco" envolvendo uma gama de políticas econômicas e sociais. Outros autores, utilizaram o termo para demonstrar a construção de certas concepções hegemônicas que alteraram as bases políticas e princípios do partido e o conduziram ao poder, nessa última abordagem não há consenso sobre o marco temporal.

${ }^{18}$ Para Rudá Ricci, ao abordar questões e hipóteses diferentes de Singer, o lulismo se configurou antes, em 2002 e cristalizou-se neste mesmo ano com a divulgação feita por Lula da Carta ao Povo Brasileiro (Cf. RICCI, 2010: 23).
} 
tocam os programas e ações desenvolvidas pelo governo Lula que ao centrar-se na

diminuição da pobreza e da desigualdade (...) avançou por meio de uma estranha combinação de orientações antitéticas: de um lado, manteve linhas de conduta do receituário neoliberal, e de outro, adotou mecanismos de uma plataforma desenvolvimentista. Essa combinação sui generis de mudança e ordem explicaria por que o apoio político ao presidente, grosso modo, migrou da classe média para o subproletariado. (SINGER, 2009: online)

$\mathrm{O}$ autor identifica que, frente as crises ocorridas no primeiro mandato do PT, ainda que não como variável-chave, mas, aliado a outros fatores (controle de preços da cesta básica, o aumento do salário mínimo, o crédito consignado e outros programas focalizados) o PBF teve grande peso na transformação do quadro de eleitores do partido. O conjunto dos programas sociais, delineados entre 2003 e 2005, somados à liderança de Lula, para Singer, são característicos da emergência do lulismoe o pano de fundo de 2006 quando "ocorreu o duplo deslocamento de classe que caracteriza o realinhamento brasileiro [qu]e estabeleceu a separação política entre ricos e pobres" (SINGER, 2012: 15).

Ao abarcar em grande medida os efeitos do PBF, as concepções sobre o lulismo e o desenvolvimento de uma política social em longo prazo, entrega relances sobre os caminhos escolhidos para diferentes projetos de sociedade, então em disputa num campo de recomposição da roupagem de um projeto neoliberal. Como avaliou a Chauí nos idos de 2006: "Não é um governo de esquerda. Mas também não é um governo neoliberal" (CHAUÍ, 2006: 40). Este movimento, em suma, indica o "signo da contradição" (SINGER, 2012:29) que faz existir o lulismo.

Ricci analisa o lulismo, diferentemente de Singer, enquanto uma estratégia e um modo de gerenciar a política nacional para a qual o personagem de Lula é a expressão máxima de um discurso construído ao longo dos anos de 1980 e 1990 que o fez representante da inclusão social. O argumento do autor está centrado na análise de um longo processo de desgaste e afastamento das lideranças sociais. Da análise da pauta política petista, Ricci considera que o 
PBF figura no cenário político como a eliminação das chances de organização política já que opera a integração dos marginalizados pela via do Estado, sendo o "mais emblemático das intenções não participacionistas do lulismo" (RICCI, 2010: 19).

Senna et al. observam o novo modelo de gestão integrada entre esferas governamentais no PBF, e questionam se o programa demarca uma nova institucionalidade na política social brasileira frente aos desafios postos à esta pauta desde a redemocratização do país. Em contraponto com as principais lacunas operacionais de programas implementados nos anos de 1990, as autoras registraram que os moldes do PBF encontram seus limites nas formas de controle social, de focalização e de gestão compartilhada (SENNA et. al., 2007).

Sublinha-se que tais limites são expressivos da agenda política do lulismo, e permitem identificar pontos de virada em uma plataforma partidária que emergiu da organização popular comunitarista - em ampla medida influenciada e organizada pela Igreja católica - e que se consolidou a partir da perspectiva de gestão institucional. Nesse sentido, a mudança de rumos nos projetos e programas petistas antes fincados nas mobilizações de combate à fome que marcaram os anos de 1990 - enraizados na participação e mobilização popular - significou também a mudança de um controle social popular para a vigilância sócio econômica e para a assistencial dos sujeitos identificados como pobres.

Há dois elementos desta mudança que podem ser notados a partir da análise sobre como o PBF é reivindicado - até então - enquanto a expressão máxima da política social para o período da Nova República. O primeiro referese ao debate sobre o abandono ou não das características participacionistas "originais" da proposta do PT, pois está diretamente relacionado ao formato de uma política nacional de transferência de renda que consolidou o produto de tendências anteriores. Tais tendências foram renovadas no corpo do PBF, que ainda tem seu próprio saldo social e político em disputa. Essa incorporação de 
normativas econômicas e sociais anulou, portanto, a coexistência de projetos opostos como possibilidades à democracia e ao horizonte do debate político.

O segundo elemento é o que expressa a dificuldade "para acertar um acordo de colaboração pacífica entre capital e trabalho em torno de políticas distributivas" (COELHO, 2005: 514). As questões em torno desse segundo ponto passam pelas possibilidades históricas e como foram materializadas em conjunturas específicas. Daí que, independentemente dos marcos estabelecidos por diferentes autores ao tratar das transformações no PT das quais derivam a ideia de lulismo, de sua capilaridade social e de seus reflexos na gestão da vida política, é direção comum na bibliografia analisada que a Carta ao Povo Brasileiro, divulgada em 22 de junho de 2002, marcou um processo de rupturas com a tradicional pauta petista em um prelúdio do que seria, para o PT seu processo de transição e síntese.

A Carta prenunciou o caráter de "um movimento em defesa do Brasil" com "prefeitos e parlamentares de partidos não coligados com o PT [que] anunciam seu apoio" junto a "parcelas significativas do empresariado [que] vêm somar-se ao nosso projeto" em uma "vasta coalizão, em muitos aspectos suprapartidária, que busca abrir novos horizontes para o país"; em referência à construção da governabilidade. O povo, por sua vez "recusa qualquer forma de continuísmo seja ele assumido ou mascarado", assim, seria "necessária uma lúcida e criteriosa transição entre o que temos hoje e aquilo que a sociedade reivindica". O novo modelo proposto seria "fruto de uma ampla negociação nacional, que deve conduzir a uma autêntica aliança pelo país, a um novo contrato social, capaz de assegurar o crescimento com estabilidade”. O compromisso firmado foi o de "combate à inflação, mas acompanhado do crescimento, da geração de empregos e da distribuição de renda, construindo um Brasil mais solidário e fraterno, um Brasil de todos" (SILVA, 2002).

Como nota Anderson (2011: 27), a Carta expressou o compromisso de Lula com o empresariado. Na avaliação de Rocha (2013: 79), contribuiu para a vitória de Lula ao ampliar sua base eleitoral, pois o candidato com suas "raízes operárias, tornava crível a bandeira do Partido de promover a geração de 
empregos, melhoria na distribuição de renda e criação de um mercado de consumo de massa".

Com a eleição de Lula à Presidência em 2002, o chamado para a mobilização social saiu do território da ação política popular e passou à ação institucionalizada pelo Estado. O combate à fome por meio de uma política de acesso aos alimentos, mesmo reconhecidamente não sendo mais uma questão urgente no Brasil, ${ }^{19}$ ganhou força na figura do próprio Lula com a sua amplamente conhecida afirmação de que se eleito sua missão seria a de garantir que todos os brasileiros pudessem ter café da manhã, almoço e jantar (BRASIL, 2003). A categoria da pobreza volta, portanto, ao cenário político nacional reinterpretada como possibilidade de articulação entre as esferas econômica, política e social.

Neste aspecto, o PBF emergiu não em um contexto esvaziado de conflitos ou que teria sido preenchido apenas por um compromisso pessoal de Lula. Foi moldado pelo jogo político, pela organização de uma economia neoliberal gestada nos governos de Collor, Franco e Cardoso e amparado em propostas que surgiram na experiência da mobilização social e popular dos anos 1990. Entrementes, muito da discussão sobre os objetivos e a estrutura do PBF passa pela tomada de posição em defesa de que o programa não tem por objetivo apenas transferir renda. Na esteira de uma resposta às mobilizações sociais em torno de um tipo de democracia cidadã, essa defesa é também a defesa das escolhas políticas que sustentam o PBF.

A relação entre a solidariedade e a pobreza, observada como mecanismo de legitimação dos programas sociais, permite notar que a apropriação do controle social - então compreendido enquanto uma forma de controle democrático (BEHRING; BOSCHETTI, 2006) - impulsionou, por meio do mecanismo das condicionalidades, a implementação da focalização como norma para os programas sociais de transferência condicionada de renda. As escolhas feitas para a gestão do PBF e do controle das condições de vida da

\footnotetext{
19 “(...) era bem sabido na época que o acesso aos alimentos e a incidência da fome como síndrome física já não eram questões críticas no Brasil.” ROCHA, 2013.
} 
população empobrecida, de certa forma, estabeleceram a medida da participação social nesse processo.

No corpo do PBF, o componente das condicionalidades é o mecanismo que pretende estabelecer a conexão entre a transferência de renda e o acesso aos direitos sociais. Desse modo, o programa procura oferecer suporte ao alargar as "capacidades de seus beneficiários por meio do reforço ao acesso a serviços de saúde, educação e assistência social, bem como na articulação com um conjunto amplo de programas sociais" (CAMPELLO: 2013: 11).

Para a manutenção do benefício monetário, as famílias precisam cumprir 'contrapartidas' sociais, ou seja, as condicionalidades relacionadas à saúde e à educação. Estas, têm um papel importante na tentativa de aceitação social do PBF e em coadunar as concepções sobre as "portas de saída" (COHN, 2013: 223). Na prática, cidadania e direitos sociais aparecem então vinculados e transformados em um dos benefícios do programa; as condicionalidades, ou seja, os direitos sociais, são entregues ao seu público alvo como contrapartidas sociais.

No processo de conciliação entre interesses opostos, no corpo do PBF, as condicionalidades foram vocalizadas como forma de exercício da cidadania e de "superação da dicotomia entre as políticas sociais scricto sensu (voltadas para o aumento das capacidades individuais) e as políticas compensatórias (voltadas para o atendimento de necessidades imediatas)", em um movimento que expressa, conforme relatado por Monteiro (2011: 69), "a importância de se investir em políticas compensatórias com "potencial emancipatório"”.

É importante notar, que como rearranjo de vários programas, surgidos em contextos específicos, o PBF organiza e incorpora não apenas as características de gestão técnica desses programas, mas o entendimento que os forjou, a concordância sobre os termos pelos quais seria aceitável transferir renda aos trabalhadores em baixas condições materiais de vida, de modo a levar adiante um projeto que implica na continuidade da expropriação dos direitos sociais. 
$\mathrm{O}$ argumento de que para cada "cada fator de vulnerabilidade" estava posta "uma 'contrapartida social' da família" (BRASIL, 2003), adequou a experiência social em torno de condições materiais de vida, como forma de minorar os efeitos do projeto de desenvolvimento econômico. Os objetivos e resultados do PBF instituíram uma nova moeda para a cidadania. Esta, circula e é medida não apenas pelos indicadores de saída individual da condição considerada de pobreza para patamares de rendimento mínimo. Mas por seu saldo, que é a medida do retorno financeiro do PBF, para o qual observa-se que "os recursos aplicados no programa teriam, em 2006, o efeito multiplicador no PIB de 1,44, e de 2,25 na renda familiar total. Ou seja, o gasto adicional de $1 \%$ do PIB no programa geraria um aumento de $1,44 \%$ do PIB e de $2,25 \%$ na renda das famílias" (PAIVA et. al.: 2013: 38).

Esse saldo é frequentemente mencionado em momentos de divulgação ou defesa política e econômica do programa. $\mathrm{O}$ argumento é de que o benefício não se restringe aos que são diretamente beneficiados, mas à toda sociedade. $\mathrm{O}$ projeto do lulismo organiza um contexto sobre a importância do PBF enquanto programa de distribuição de dinheiro - que envolve a ideia de aquecimento do mercado interno e da economia regional como método para o desenvolvimento econômico a partir de formas específicas de desenvolvimento social. Como argumentou Lula, "é barato e fácil cuidar dos pobres" (ANDERSON, 2011:51) e em 2009, o valor total do PIB destinado ao PBF era de 0,4\% (Neri et al., 2013: 198). A divulgação e defesa do PBF por esta perspectiva, evidencia sua localização na esteira dos mecanismos de oposição à rede de proteção social universal então prevista no rol dos Direitos Sociais. Estes foram reconfigurados ao longo dos anos de 1990 sob as políticas de ajuste macroeconômico, que promoveram reformas nos programas sociais e bloquearam as possibilidades então inscritas no horizonte social e político.

Com o PBF, como programa que expressa uma síntese do processo histórico e social destas reformas, há a intenção da ação do Estado ser hegemônica, portanto, é preciso que a convergência para atitudes comuns seja mantida por meio do incentivo à mudança de hábitos e de valores que são 
mediados por relações culturais. Nesse processo, ocorrem aprendizagens que seriam, como pontua Gohn: "a internalização de hábitos e valores transmitidos" (GOHN, 2014: 67). Deste modo, as interpretações institucionais em torno do PBF como forma exemplar para se lidar com a pobreza, precisam ser legitimadas a partir da mobilização de leituras que sejam socialmente aceitas, gerando certa coesão social que, na contramão do acesso universal aos Direitos Sociais, orbita em torno de categorias como pobreza, consumo e da mobilização de sentimentos de dignidade.

\section{Considerações Finais}

A análise do processo de reformas nos programas sociais, permite compreender como e porquê se chegou ao corpo atual do $\mathrm{PBF}$, ainda que a partir de um projeto forjado em meio a amplos movimentos de mobilização popular que carregavam noções de uma identidade política solidária e de formação de concepções em torno de justiça social. A pobreza elevada à centralidade dos programas sociais, como categoria política, foi qualificada pela identificação de uma parcela da população como "pobres" pelo mecanismo da focalização.

Enquanto categoria política esvaziada das interpretações acerca das experiências sociais antagônicas que a qualificam enquanto condição material de vida, encontrou eco no exercício de controle político e social, junto ao argumento de desenvolvimento econômico. Este deslocamento permitiu a vinculação do sentimento de cidadania ao acesso ao dinheiro, como veículo principal para o consumo e, portanto, expressão da mobilidade social como fator individual. Matizou-se, desta forma, o fato de que a pobreza não é simplesmente um dado, mas uma forma real de organização das relações sociais.

Os sentidos atribuídos aos programas sociais pelas reformas no contexto do lulismo, com o PBF enquanto expressão de eficiência da gestão das políticas sociais, permitem notar reinterpretações de diferentes atitudes morais frente às 
experiências vividas na dimensão das relações de produção, pressionando-as para que a mediação e a conciliação entre interesses divergentes possa se materializar. Dessa forma, se uma maior parcela da população está a assimilar novos valores para os direitos sociais é possível que estruturas hierárquicas de relação também estejam. Uma das questões colocadas consiste em notar que em meio ao circuito institucional dos programas sociais, não há nada que questione as relações de subordinação social enquanto expressão da individualização de concepções em torno dos Direitos Sociais.

Analisar as formas pelas quais foi possível avançar socialmente sem mudar concepções estruturantes em torno da fome e da pobreza, então deslocadas para os objetivos da conciliação política e do controle social, auxilia na compreensão de que a partir da identificação da figura do "pobre" pelo instrumental técnico do $\mathrm{PBF}$, formas constituídas de regulação que não são completamente centrais nem homogêneas, são apropriadas de diversas maneiras nos limites do comportamento esperado para a conciliação e o controle. Tais limites estão imersos em um campo de conflitos e antagonismos que podem não atender ao que é centralmente esperado.

Como nota Willis (1991), há um entrecampo das relações sociais que não indica nem a completa aceitação e nem a completa subordinação de sujeitos que estão inseridos em determinada lógica institucional. Para o autor, "Só porque existe aquilo que podemos chamar de determinantes estruturais e econômicos não significa que as pessoas se curvarão a eles sem maiores problemas" (WILLIS, 1991: 211). Este entrecampo, no caso das reformas nos programas sociais, é onde se pode evidenciar um tipo de significação para as relações vividas que resulta em uma aparência sócio cultural

Com a alteração do conteúdo de mobilização social que se manifestava em torno da ideia de solidariedade, o conjunto das relações que a ligava à pobreza foram também alterados. Assim, não necessariamente antagonismos entre classes deixaram de existir ou os conteúdos dos programas sociais foram esvaziados de seu conteúdo político. Assumiram, pois, outras formas de negação, controle, negociação, interpretação e conflito que não necessariamente 
se colocaram como transformadoras, mas que foram validadas pelas circunstâncias históricas em que foram forjadas.

Esse processo, ao ser organizado de "cima para baixo" não propôs novos filtros e medidas morais que pudessem mediar simbolicamente transformações nas formas como as relações sociais estão organizadas. Nesse sentido, medidas e filtros morais anteriores ao PBF continuaram a se impor como forma de interpretação das condições materiais vividas pelos beneficiários do programa. É no campo da fiscalização social - que sustenta a focalização do programa - que valores sociais e práticas econômicas são impostas enquanto técnica social modelada a partir de particularidades. Nesse sentido, uma das tendências que se faz notar é que, em meio a diferentes especificidades de projetos políticos e econômicos, e quanto mais interessado estiver o corpo político do governo federal em exercício em aprofundar as bases de desenvolvimento econômico, com relação ao PBF, as alterações não se darão pela disputa sobre seu conteúdo técnico, mas pelas formas de sua legitimação social.

\section{Referências}

AB'SABER, Tales. Lulismo - Carisma pop e cultura anticrítica. São Paulo: Hedra, 2016 [2. Ed].

A verdade vencerá: o povo sabe por que me condenam / Luiz Inácio Lula da Silva [et al.]; organização Ivana Jinkings - 1. ed. - São Paulo: Boitempo, 2018.

ANDERSON, Perry. O Brasil de Lula. Novos Estudos. CEBRAP, São Paulo, n. 91, pp. 23-52, nov. 2011.

BEHRING, Elaine Rossetti; BOSCHETTI, Ivanete. Política Social: fundamentos e história. São Paulo: Cortez Editora, 2012. [Biblioteca básica de serviço social, vol. 2]. e-pub.

BETTO, Frei. Fome Zero: Ganhos e Perdas. In: Fome Zero: Uma História Brasileira. Org.: Adriana Veiga Aranha. - Brasília, DF: Ministério do Desenvolvimento Social e Combate à Fome, Assessoria Fome Zero, v. 1, 2010. pp. 133-139.

BRASIL. Cidadania e Justiça. Desenvolvimento Social. Em 12 anos, Bolsa Família retirou 36 milhões de pessoas da extrema pobreza. 19 out. 2015. Modificado em 4 nov. 2015. Disponível em: < http://www.brasil.gov.br/cidadania-e-justica/2015/10/em12-anos-bolsa-familia-retirou-36milhoes-de-pessoas-da-pobreza- 
extrema?TSPD_101_R0=fa15a1708c18c79b3a3a19256c4c837exOK00000000000000 007ce936bfffff000 00000000000000000000000005 af49859005d7b8962 >. Consultado em: 28 abr. 2018.

BRASIL. Presidência da República, Casa Civil, Subchefia para Assuntos Jurídicos. E.M. $n$ 47/ C. Civil-PR. Brasília, 20 out. 2003. Disponível em: $<$ http://www.planalto.gov.br/ccivil_03/Exm/2003/EM47-CCIVIL-03.htm>.

Consultado em: 24 jul. 2017.

BRASIL. Biblioteca da Presidência da República. Presidência da República. Secretaria de Imprensa e Divulgação. Discurso do Presidente da República. Pronunciamento do Presidente da República, Luiz Inácio Lula da Silva, na sessão solene de posse no Congresso Nacional. Brasília - DF, 01 de janeiro de 2003. p.4. Disponível em:<http://www.biblioteca.presidencia.gov.br/presidencia/ex-presidentes/luiz- inaciolula-da silva/discursos/discursos-de-posse/discurso-de-posse-1o-mandato/view>. Consultado em: 21 jul. de 2017.

CAMPELlO, Tereza; NERI, Marcelo Cortês. Apresentação. In: Programa Bolsa Família: uma década de inclusão e cidadania / organizadores: Tereza Campello, Marcelo Côrtes Neri. - Brasília: Ipea, 2013. pp. 11-12.

COELHO, Eurelino. Uma esquerda para o Capital - Crise do Marxismo e Mudanças nos Projetos Políticos dos Grupos Dirigentes do PT (1979-1998). Tese. Programa de Pós-Graduação em História da Universidade Federal Fluminense. Niterói, 2005.

COHN, Amélia. Desafios de uma trajetória de êxito: dez anos do PBF. In: Programa Bolsa Família: uma década de inclusão e cidadania / organizadores: Tereza Campello, Marcelo Cortês Neri. - Brasília: Ipea. pp. 455-466.

CHAUÍ, Marilena. A ética da Política - Entrevista com Marilena Chauí. In: Leituras da crise: Diálogos sobre o PT, a democracia brasileira e o socialismo / Marilena Chaúi... [et al.] - 1 ed. - São Paulo: Editora Fundação Perseu Abramo, 2006. pp. 1756.

DE SORDI, Denise N. Reformas nos Programas Sociais brasileiros: Solidariedade, Pobreza e Controle social $(1990$ - 2014). Tese (Doutorado). Programa de PósGraduação em História (PPGHI), da Universidade Federal de Uberlândia (UFU). 2019. 316p. Disponível em: http://dx.doi.org/10.14393/ufu.te.2019.615.

DE SORDI, D. As perigosas mudanças no Cadastro Único, o Bolsa Família e o Brasil rumo ao Mapa da Fome. El País - Brasil. 01 fev. 2021. Disponível em: < https://brasil.elpais.com/brasil/2021-02-01/as-perigosas-mudancas-no-cadastro-unicoo-bolsa-familia-e-o-brasil-rumo-ao-mapa-da-fome.html>. Acesso em: 16 março de 2021.

EXAME. Sair do Mapa da Fome da ONU é histórico diz governo. 16 set. 2014. Disponível em: <https://exame.abril.com.br/brasil/sair-do-mapa-de-fome-da-onu-ehistorico-diz-governo/>. Consultado em: 28 abr. 2018.

GOHN, Maria da Glória. A Ação da Cidadania Contra a Miséria e Pela Vida - Ou quando a fome se transforma em questão nacional. In: Formas de Combate $e$ 
Resistência à Pobreza / Organização de Luiz Inácio Gaiger. - São Leopoldo: Ed. Unisinos, 1996. pp.23-58.

. Teorias dos Movimentos Sociais - Paradigmas clássicos e contemporâneos. 3. ed. 2002. São Paulo: Edições Loyola, 1997.

_. Novas Teorias dos movimentos sociais. $5^{\circ}$ ed. - São Paulo: Edições Loyola, 2014.

GRANEMANN, S. Para uma Crítica Marxista das Políticas Sociais. In: Marx e o Marxismo 2011: teoria e prática. UFF - Niterói, RJ. NIEP MARX. 28/11/2011 a $01 / 12 / 2011$.

GUSMÃO, Rute. A ideologia da solidariedade. Serviço Social \& Sociedade, ${ }^{\circ}{ }^{\circ}$. São Paulo: Cortez, 2000. pp. 93-112.

IBASE. Betinho símbolo de cidadania. Disponível em: < http://www.ibase.br/pt/perfilbetinho/> . Acesso em 14 set. de 2014.

JORDÃO, João; VARELA, Raquel; PEREIRA, Rui V. Segurança Social: Fundo Universal de Solidariedade ou Mercado Privado de Capitais? Entrevista com Sara Granemann. In: VARELA, Raquel. (coordenação). A segurança social é sustentável Trabalho, Estado e Segurança Social em Portugal. Lisboa: Bertrand Editora, 2013. pp. 151-170.

MARTUSCELLI, D. E. O PT e o impeachment de Collor. Opinião Pública, Campinas, vol. 16, n 2, pp. 542-568, nov. 2010.

MAURIEL, Ana Paula Ornellas. Combate à pobreza e desenvolvimento humano: impasses teóricos na construção da política social na atualidade. Tese. Programa de Pós-Graduação em Ciências Sociais. Unicamp: 2008.

MENEZES, Francisco. Mobilização Social e Participação da Sociedade Civil. In: Fome Zero: Uma História Brasileira. Org.: Adriana Veiga Aranha. - Brasília, DF: Ministério do Desenvolvimento Social e Combate à Fome, Assessoria Fome Zero, v. 1, 2010. pp.120-132.

MONTAÑO, Carlos. Terceiro setor e questão social: crítica ao padrão emergente de intervenção social. 6. ed. - São Paulo: Cortez, 2010.

MONTEIRO, Iraneth Rodrigues. Integração de políticas sociais: um estudo de caso sobre o Bolsa Família / Rio de Janeiro: 2011. Dissertação (Mestrado Profissional em Bens Culturais e Projetos Sociais) pelo CPDOC/FGV.

MURPHY, Priscilla. Diretor do banco, Vinod Thomas, diz que Bolsa-Família será modelo para outros países. O Estado de S. Paulo. Nacional. p. A 6. 21 out. 2003. Disponível em: < http://acervo.estadao.com.br/pagina/\#!/20031021- 40180-spo-6-pola6-not >. Consultado em: 24 abril 2018.

NERI, M. C.; et al. Efeitos macroeconômicos do programa bolsa família: uma análise comparativa das transferências sociais. In: Programa Bolsa Família: uma década de 
inclusão e cidadania / organizadores: Tereza Campello, Marcelo Côrtes Neri. Brasília: Ipea, 2013. pp.193-206.

OLIVEIRA, Francisco de. Brasil: Uma biografia não autorizada / Francisco de Oliveira. - 1. ed. - São Paulo: Boitempo, 2018.

_. Política numa era de indeterminação: opacidade e reencantamento. In: A Era da indeterminação / [Francisco de Oliveira, Cibele Saliba Rizek, organizadores]. - São Paulo: Boitempo, 2007. pp. 15-45

PAIVA, L. H.; FALCÃO, T.; BARTHOLO, L. Do Bolsa Família ao Brasil Sem Miséria: Um resumo do percurso brasileiro recente na busca da superação da pobreza Extrema. In: Programa Bolsa Família: uma década de inclusão e cidadania / organizadores: Tereza Campello, Marcelo Côrtes Neri. - Brasília: Ipea, 2013. pp. 2546.

PELIANO, Anna Maria Medeiros. Lições da História - avanços e retrocessos na trajetória das políticas públicas de combate à fome e à pobreza no Brasil. In: Fome Zero: Uma História Brasileira. Org.: Adriana Veiga Aranha. - Brasília, DF: Ministério do Desenvolvimento Social e Combate à Fome, Assessoria Fome Zero, v. 1, 2010. pp. 26-40.

PERES, Thais Helena de Alcântara. Comunidade Solidária - A proposta de um outro modelo para as políticas sociais. Civitas. Porto Alegre, v.5, n. 1, pp. 109-126, jan./jun. 2005.

PINTO, Céli Regina Jardim. A sociedade civil e a luta contra a fome no Brasil. Sociedade e Estado, Brasília, v. 20, pp. 195-228, jan./abr. 2005.

RICCI, Rudá. Lulismo - Da Era dos Movimentos Sociais à Ascensão da Nova Classe Média Brasileira. / Rudá Ricci - Brasília: Fundação Astrojildo Pereira, 2010.

ROCHA, Sonia. Pobreza - Afinal, do que se trata / Sonia Rocha. - $3^{\circ}$ ed. - Rio de Janeiro: Editora FGV, 2006.

_. Transferências de Renda: o fim da pobreza / Sonia Rocha. - Rio de Janeiro: Elsevier, 2013.

SADER, Eder. Quando novos personagens entraram em cena: experiências, falas e lutas dos trabalhadores da Grande São Paulo, 1970-80. Rio de Janeiro: Paz e Terra, 1988.

SCHWARCZ, Lilia Moritz. Brasil: uma biografia. / Lilia Moritz Schwarcz e Heloisa Murgel Starling - $1^{\circ}$ ed. - São Paulo: Companhia das Letras, 2015.

SENNA, Mônica de Castro Maia, MONNERAT, Giselle Lavinas, SCHOTZZ, Vanessa et al. Bolsa Família: nova institucionalidade no campo da política social brasileira? Rev. Kátal. Florianópolis, v.10, n.1, pp. 87-94, jan/jun. 2007. 
SILVA, José Graziano da. Entrevista In: Fome Zero: Uma História Brasileira. Org.: Adriana Veiga Aranha. - Brasília, DF: Ministério do Desenvolvimento Social e Combate à Fome, Assessoria Fome Zero, v. 1, 2010. pp. 96-104.

SILVA, Luiz Inácio Lula da. Carta ao Povo Brasileiro. São Paulo, 22 de junho de 2002. Fundação Perseu Abramo. Resoluções de Encontros \& Programas de Governo. - Partido dos Trabalhadores.

SILVA, Luiz Inácio Lula da. Prefácio. In: Fome Zero: Uma História Brasileira. Org. : Adriana Veiga Aranha. - Brasília, DF: Ministério do Desenvolvimento Social e Combate à Fome, Assessoria Fome Zero, v. 1, 2010.

SINGER, André. O lulismo em Crise: um quebra-cabeça do período Dilma (20112016). $1^{\circ}$ ed. - São Paulo: Companhia das Letras, 2018.

_. Os sentidos do lulismo: reforma gradual e pacto conservador. $1^{\circ}$ ed. - São Paulo: Companhia das Letras, 2012.

_. O lulismo e seu futuro. Piauí. Rio de Janeiro, ed. 49, out. 2010.

SOUZA, Herbert de ('Betinho'). Fonte original: Ação, 55, dez., 1993. Publicado em 01 jan. 2015. Associação Nacional dos Funcionários do Banco do Brasil (ANABB). Disponível em: https://www2.anabb.org.br/Portal/Noticia/Visualizar/95348/Entrevista-Herbert-deSouza- \%27Betinho\%27>. Consultado em: 24 set. 2018.

SOUSA, Patrus Ananias de. Entrevista. In: Fome Zero: Uma História Brasileira. Org.: Adriana Veiga Aranha. - Brasília, DF: Ministério do Desenvolvimento Social e Combate à Fome, Assessoria Fome Zero, v. 1, 2010.

TELLES, Vera da S. Pobreza e Cidadania / Vera da Silva Telles. $-2^{\circ}$ ed. - São Paulo: Programa de Pós-Graduação em Sociologia da FFLCH-USP/Editora 34, 2013.

THOMPSON, E. P. A Miséria da Teoria - ou um planetário de erros (uma crítica ao pensamento de Althusser). trad. Waltensir Dutra. Rio de Janeiro: Zahar, 1981.

VANNUCCHI, C. Cronologia de Luiz Inácio Lula da Silva. In: A verdade vencerá: o povo sabe por que me condenam / Luiz Inácio Lula da Silva [et al.]; organização Ivana Jinkings - 1. ed. - São Paulo: Boitempo, 2018. pp. 199-212.

Recebido em: 26 de fevereiro de 2020

Aceito em: 10 de março de 2021 